\title{
THE STUDY OF SPECTRUM OF HYPOSPADIAS AND EVALUATION OF ITS ASSOCIATED ANOMALIES IN EASTERN PARTS OF INDIA
}

\author{
Sudhansu Sekhar Patra1, Narendra Nath Swain ${ }^{2}$
}

${ }^{1}$ Assistant Professor, Department of Surgery, Hi-Tech Medical College, Bhubaneswar, Odisha.

${ }^{2}$ Assistant Professor, Department of Surgery, SCB Medical College, Cuttack, Odisha.

ABSTRACT
BACKGROUND
The incidence of developmental anomalies and disabilities associated with hypospadias is controversial and varies in different
studies in different places. We describe the study of incidence of different types of hypospadias and its associated anomalies in this
part of world.

\section{MATERIALS AND METHODS}

145 cases of different types of hypospadias were studied at three different centres of eastern part of India and the result was analysed.

\section{RESULTS}

The overall incidence of associated anomalies in this series was $29.65 \%$. Undescended testis was the most common anomaly $(8.27 \%)$ followed by inguinal hernia and vesicoureteral reflux with incidence of $6.89 \%$ each.

\section{CONCLUSION}

The incidence of distal penile hypospadias was highest among others in this study. Genitourinary anomalies were the most common associated anomalies in this study followed by anorectal malformations. Among the genitourinary anomalies, undescended testis was the most common anomaly followed by inguinal hernia and vesicoureteral reflux.

\section{KEYWORDS}

Hypospadias, Distal Penile Hypospadias.

HOW TO CITE THIS ARTICLE: Patra SS, Swain NN. The study of spectrum of hypospadias and evaluation of its associated anomalies in eastern parts of India. J. Evolution Med. Dent. Sci. 2017;6(34):2798-2800, DOI: 10.14260/Jemds/2017/603

\begin{abstract}
BACKGROUND
Hypospadias can be defined as an arrest in normal development of the urethra, foreskin, and ventral aspect of the penis. This results in a wide range of abnormalities. The urethral opening can be anywhere along the ventral shaft of the penis, within the scrotum, or even in the perineum. Hypospadias is usually associated with a ventral curvature of the penis i.e. chordee.
\end{abstract}

\section{Hypospadias Classification (Duckett - 1996) According to} Meatal Location after Release of Chordee ${ }^{1}$

- Anterior (50\% of cases).

- Glanular.

- Sub-coronal.

- Middle (30\% of cases).

- Distal penile shaft.

- Middle penile shaft.

- Proximal penile shaft.

- Posterior (20\% of cases).

Financial or Other, Competing Interest: None.

Submission 30-03-2017, Peer Review 15-04-2017,

Acceptance 19-04-2017, Published 27-04-2017.

Corresponding Author:

Dr. Narendranath Swain,

Plot No. 1194/30,

Sector-6, CDA,

Cuttack-753014, Odisha.

E-mail: swainsurgery@gmail.com

DOI: $10.14260 /$ jemds $/ 2017 / 603$
- Penoscrotal.

- Scrotal.

- Perineal.

The underlying cause for nonsyndromic hypospadias in most individual cases is unknown. A unifying aetiology for hypospadias remains elusive. Hypospadias probably results from multiple factors. The hypospadiac anatomy appears consistent with incomplete embryologic development as a result of-

1. Abnormal androgen production by the foetal testes.

2. Limited androgen sensitivity of the receptors in target tissues of the developing genitalia.

3. Premature cessation of androgenic stimulation due to early atrophy of the Leydig cells of the testes. ${ }^{2}$

The incidence of developmental anomalies and disabilities associated with hypospadias is controversial and varies in different studies in different places.

\section{MATERIALS AND METHODS}

This study is a retrospective analysis of data from three leading medical colleges in eastern part of India, i.e. N. R. S. Medical College and Hospital, Kolkata; S.C.B. Medical College and Hospital, Cuttack; and Hi-Tech Medical College and Hospital, Bhubaneswar. The period of study was from September 2011 to August 2016. 145 hypospadias cases of all religions and socioeconomic classes included in this study. All cases with disorders of Sexual Differentiation were excluded from the study. Cases were analysed in respect of age at 
presentation, different types of hypospadias and associated anomalies.

\section{RESULTS}

\begin{tabular}{|c|c|c|}
\hline Age in Years & Total No. of Cases & \% of Total Cases \\
\hline $1-4$ & 61 & 42.06 \\
\hline $5-10$ & 71 & 48.97 \\
\hline$>10$ & 13 & 8.97 \\
\hline \multicolumn{3}{|c|}{ Table 1. Age Distribution } \\
\hline
\end{tabular}

A total of 145 cases included in this study. The age of the patients ranged from 1 year to 12 years of age with a median age of 5 years. In this study, the patients were divided into three age groups. Majority of cases were in the group of 5 to 10 years, followed by the group of 1 to 4 years. Surgery was not performed on patients younger than 1 year of age as the size of the penis is small.

\begin{tabular}{|c|c|c|}
\hline $\begin{array}{c}\text { Type of } \\
\text { Hypospadias }\end{array}$ & $\begin{array}{c}\text { Total No. of } \\
\text { Cases }\end{array}$ & $\begin{array}{c}\text { \% of Total } \\
\text { Cases }\end{array}$ \\
\hline Glanular & 11 & 7.59 \\
\hline Subcoronal & 15 & 10.35 \\
\hline Distal penile & 60 & 41.38 \\
\hline Mid penile & 15 & 10.35 \\
\hline Proximal penile & 24 & 16.55 \\
\hline Penoscrotal & 16 & 11.04 \\
\hline Scrotal & 2 & 1.37 \\
\hline Perineal & 2 & 1.37 \\
\hline \multicolumn{2}{|r}{ Table 2. Type of Hypospadias } \\
\hline
\end{tabular}

In this study, majority of cases were distal penile hypospadias followed by proximal penile and penoscrotal hypospadias. Two cases each of scrotal and perineal hypospadias were operated in this study. According to recent working classification, distal type which includes coronal, distal penile and mid-penile variety forms the bulk of the study group.

\begin{tabular}{|c|c|c|c|c|c|}
\hline $\begin{array}{c}\text { Associated } \\
\text { Anomalies }\end{array}$ & $\begin{array}{c}\text { Right } \\
\text { Side }\end{array}$ & $\begin{array}{c}\text { Left } \\
\text { Side }\end{array}$ & B/L & $\begin{array}{c}\text { Total } \\
\text { No. }\end{array}$ & \% \\
\hline Undescended Testis & 04 & 06 & 02 & 12 & 8.27 \\
\hline Inguinal Hernia & 04 & 05 & 01 & 10 & 6.89 \\
\hline Vesicoureteral Reflux & 06 & 04 & 0 & 10 & 6.89 \\
\hline $\begin{array}{c}\text { Posterior Urethral } \\
\text { Valve }\end{array}$ & - & - & - & 01 & 0.68 \\
\hline Nephrolithiasis & - & - & - & 01 & 0.68 \\
\hline $\begin{array}{c}\text { Anorectal } \\
\text { Malformation }\end{array}$ & - & - & - & 06 & 4.14 \\
\hline $\begin{array}{c}\text { Hirschsprung's } \\
\text { Disease }\end{array}$ & - & - & - & 02 & 1.37 \\
\hline Wilms' Tumour & 01 & 0 & 0 & 01 & 0.68 \\
\hline \multicolumn{2}{|c|}{ Table 3. Associated Anomalies } \\
\hline
\end{tabular}

In this study, most common associated anomalies were genitourinary ones, out of which the most common is undescended testis. The incidence in this study was $8.27 \%$. There were 2 cases of B/L palpable undescended testes, and left-sided undescended testis was more common than right side. The incidence of inguinal hernias in this series was $6.89 \%$ which is second most common associated anomaly. One case was $\mathrm{B} / \mathrm{L}$ and left sided hernias were more common than right side.

The next common associated anomaly was vesicoureteral reflux. The incidence of VUR in this study was $6.89 \%$, and right-sided VUR was more common than left-sided VUR. All the cases are in follow-up, and none of them required surgery for VUR at present. Other associated anomalies were anorectal malformation, Hirschsprung's disease, Wilms' tumour, posterior urethral valve, etc.

\section{DISCUSSION}

\section{Age Distribution}

In this study, $48.97 \%$ cases were between 5 and 10 years of age followed by 1 to 4 years group (42.06\%). Cases older than 10 years of age were few in number $(8.97 \%)$. The median age in this study is 5 years. Although parents were aware of this type of anomaly after birth, they used to come late after the boy faced problems in his peer group or in the school. The main complaint is backward direction of the urinary flow leading to soiling of garments which forced the boy to squat and urinate like girls.

\section{Type of Hypospadias}

In this study, the most common type was anterior variety with distal penile hypospadias. The incidence of distal penile hypospadias was $41.38 \%$ followed by the incidence of proximal penile hypospadias $(16.55 \%)$. The incidence of extreme varieties of hypospadias like scrotal and perineal types was very much low in this study. The incidence of different types of hypospadias is comparable with the study by Marek Orkiszewski in which the incidence of distal penile type was 38\%. ${ }^{3}$ But our incidence differed from those of the study by Wang-Hseng $\mathrm{Wu}$ et al where $24.7 \%$ had anterior, $9.6 \%$ mid-penile and $65.7 \%$ posterior hypospadias. 4

\section{Associated Anomalies}

The overall incidence of associated anomalies in this series was $29.65 \%$. The overall incidence of associated anomalies is comparable to those in the series by Wang-Hseng Wu et al. ${ }^{5}$

Genitourinary anomalies were most commonly associated in this study. Undescended testis was the most common anomaly $(8.27 \%)$ followed by inguinal hernia and vesicoureteral reflux with incidence of $6.89 \%$ each. In the series of Wang-Hseng $\mathrm{Wu}$ et al, the incidence of undescended testis and inguinal hernia were $7.3 \%$ and $12.4 \%$ respectively. ${ }^{5}$ Our results are also comparable with the series by BK Kulkarni et al. ${ }^{6}$ The incidence of undescended testis was $6.9 \%$ of 130 cases, vesicoureteral reflux was $5.4 \%$ and inguinal hernia was 3.8\%.

The incidence of anorectal malformation in their study was $1.7 \%$. The incidence of undescended testis in this study was lower than that found by Shima $\mathrm{H}$ et al where the incidence was $13.2 \%$. Other associated anomalies were posterior urethral valve and nephrolithiasis. ${ }^{4}$

In this series, hypospadias was associated with high anorectal malformation in $4.14 \%$ cases. There were 2 cases of Hirschsprung's disease associated with hypospadias. Wilms' tumour was present in only one case $(0.68 \%)$ in this study.

The associated anomalies in this study were dealt separately in this study.

\section{CONCLUSION}

In this study of spectrum of hypospadias and its associated anomalies, the median age at surgery was 5 years. The incidence of distal penile hypospadias was the highest among others in this study. There were only a few cases of severe types of hypospadias in this series. 
Genitourinary anomalies were the most common associated anomalies in this study followed by anorectal malformations. Among the genitourinary anomalies, undescended testis was the most common anomaly followed by inguinal hernia and vesicoureteral reflux.

\section{REFERENCES}

[1] Sheldon CA, Duckett JW. Hypospadias. Pediatr Clin North Am 1987;34(5):1259-72.

[2] Baskin LS. Hypospadias and urethral development. J Urol 2000;163(3):951-6.
[3] Orkiszewski M. A standardized classification of hypospadias. J Pediatr Urol 2012;8(4):410-4.

[4] Shima H, Ikoma F, Terakawa T, et al. Developmental anomalies associated with hypospadias. J Urol 1979;122(5):619-21.

[5] Wu WH, Chuang JH, Ting YC, et al. Developmental anomalies and disabilities associated with hypospadias. J Urol 2002;168(1):229-32.

[6] Kulkarni BK, Oak SN, Patel MP, et al. Developmental anomalies associated with hypospadias. J Postgrad Med 1991;37(3):140-3. 